\title{
Entrepreneurship Opportunities after Military Career: Practice in Central and Eastern versus Western Europe
}

\author{
Rasa Smaliukienè
}

\begin{tabular}{l} 
A B S T RACT \\
\hline Objective: This paper seeks to contribute to the discussion devoted to \\
entrepreneurship of a specific profession group - early retired servicemen. The aim of \\
the paper is to provide a composition of existing practices of entrepreneurship skills \\
development of early retired servicemen in EU member countries and evaluate the \\
differences between Central and Eastern Europe (CEE) and Western Europe (WE) \\
practice.
\end{tabular}

Research Design \& Methods: Institutional survey was employed as a methodological approach for this study. The survey questionnaire included request data on programs and services that maintain the promotion, training, counselling and financial or infrastructural support by fostering entrepreneurship activities of retired officers.

Findings: The results indicate the lack of entrepreneurship development policies for early retired servicemen, while service in military often provides highly specific competencies that can be adapted as transferable expertise and knowledge for entrepreneurship.

Implications \& Recommendations: The paper has identified the need to include entrepreneurship skills development in the reintegration programs of early retired servicemen. Development of entrepreneurship skills may prepare servicemen, who are being dismissed from the service, for new economic activities, as well as create conditions for their successful reintegration into civilian life.

Contribution \& Value Added: The paper contributes to the debates surrounding entrepreneurship of a specific professional group - early retired servicemen.

\begin{tabular}{ll}
\hline Article type: & research paper \\
Keywords: & entrepreneurship; military; early retirement \\
JEL codes: & L26, J08
\end{tabular}

Published by Centre for Strategic and International Entrepreneurship - Krakow, Poland

\section{Suggested citation:}

Smaliukienè, R. (2013). Entrepreneurship Opportunities after Military Career: Practice in Central and Eastern versus Western Europe. Entrepreneurial Business and Economics Review, 1(4), 97-108. 


\section{INTRODUCTION}

Several thousand military service members move each year from the military to civilian life. Military officers retire on average 20 years earlier than people serving in civil workplaces. One in seven veterans is self-employed or a small business owner in US (Veterans Fact Sheet, 2013). The s situation in Europe is different. The programmes for retired military reintegration into civil life are focussed on employment in public sector or big business rather than rising an interest in starting own business and becoming an entrepreneur.

This paper seeks to contribute to the debates surrounding entrepreneurship of a specific professional group - early retired servicemen. Drawing on policy variation across EU countries this study analyses the differences, similarities and the best practices in servicemen engagement into economic activities by providing them with a stimulating environment for it. The aim of the paper is to provide a composition of existing practices of entrepreneurship skills development of early retired servicemen in EU member countries and evaluate the differences between Central and Eastern Europe (CEE) and Western Europe (WE) practice.

Following this introduction, the next two sections provide the literature review and research methodology used in the study including the description of research instrument, sample selection and data collection. Section four presents the research findings starting with the evaluation of the role of pensions and compensation for servicemen as a contextual variable for entrepreneurship, following with the analysis of active labour market measures for entrepreneurship in different EU countries. The article concludes with discussion on findings and implications for future research.

\section{LITERATURE REVIEW}

In terms of servicemen entrepreneurship after their active military career, the main issue concerns the relationship between active and passive labour market policies as main motivators for self-employment (Vigoda-Gadot et al., 2010; Cawley \& Maclean, 2012; Šileika \& Bekerytè, 2013). Majority of EU member states with early retirement of servicemen (passive support) do have active programmes for their reintegration into labour market (active support) and some of those programmes encompass entrepreneurship skills development initiatives. Coordination between the two determinates the level of economic activity in civil life of early retired servicemen.

Early retirement guarantees a constant change of human resources in the national defence systems which are necessary for their regeneration. Consequently, servicemen retire on average 15-20 years earlier than people serving in civil workplaces (Henning, 2011; Wood et al., 2012). The retirement pension does not equal to income that supports the standard of living that a person had before the retirement. Early retirement ensures meeting essential needs only. In order to create and maintain their well-being, a person must continue working and receiving extra income. According to previous research (Early, 2011; Ruiz \& Morrow, 2005), about two-thirds of servicemen who entered early retirement work full-time. At the same time Hope et al. (2011) found that retired servicemen are more likely than other unemployed individuals to be self-employed. According to their findings, the probability of self-employment varies from 45 percent to as high as 88 percent. 
Middle-aged servicemen, who have been discharged and want to re-start their economic activities in civil life, experience adjustment problems and require external support. Failure to understand the needs of these people is likely to result in an unsuccessful experience for self-employment and losses in self-confidence (Brown \& Gross, 2011). De la Porte and Jacobsson (2012) used social investment approach to equip such people with the necessary skills to face change and provide supportive service to develop their entrepreneurship activities. The case of every serviceman is unique and depends on institutional factors such as previous work, attained rank or position, as well as on the individual's personal characteristics, communicability, and flexibility. Service in military for a few decades may provide a person with highly specific competencies necessary for entrepreneurship, skills like communication, group leadership, problem solving, and risk-taking (Caligiuri et al., 2011; Haerem et al., 2011; Chandra, 2013). Those competencies could be understood as transferable expertise and knowledge for entrepreneurship.

\section{MATERIAL AND METHODS}

As a methodological approach for this study, the author chose multi-institutional survey, which was a part of larger research financed by a grant (No. SIN-19/2012) from the Research Council of Lithuania. Questionnaire has been prepared based on theoretical implications in passive and active labour market policy and institutional agency in entrepreneurship development (Smaliukiene, 2014). The questionnaire included required data on programs and services that maintain the promotion, training, counselling and financial or infrastructural support by fostering entrepreneurship activities of retired officers. The questionnaire consisted of four sections. Section 1 requested basic information to identify passive support towards early retirees and initiatives in supporting employability of military/police officers to re-integrate them into the labour market after retirement. Section 2 requested information on particular

Table 1. Received answers from authorities

\begin{tabular}{|c|c|}
\hline $\begin{array}{c}\text { Received answers from military authorities } \\
\text { from: }\end{array}$ & $\begin{array}{c}\text { Information collected from } \\
\text { secondary sources about: }\end{array}$ \\
\hline Belgium & Austria \\
Czech Republic & Bulgaria \\
Denmark & Germany \\
Estonia & Ireland \\
Croatia & United Kingdom \\
Latvia & \\
Poland & \\
Luxembourg & \\
Netherlands & \\
Portugal & \\
France & \\
Romania & \\
Finland & \\
Slovakia & \\
Slovenia & \\
\hline$n=15$ & \\
\hline
\end{tabular}

Source: own study. 
activities that the government (or other institutions) is implementing for retired military/police officers. Section 3 invited to provide the assessment of existing activities in employability, while section 4 demanded information for future development in labour market reintegration programmes.

The survey was conducted by sending questionnaires to Ministries of Defence of all $(\mathrm{N}=27)$ European Union member countries using Lithuanian military attaches' network. A total 15 questionnaires of 27 were returned completed (Table 1 provides the list of the countries where information came from). Additionally, information was collected from secondary sources about policy in Austria, Bulgaria, Germany, Ireland and United Kingdom.

The survey has provided comprehensive qualitative data on different policies and practices in EU regarding reemployment of early retired officers and servicemen. The data was analysed by looking for similarities and differences within and across two groups: (1) Eastern and Central European countries, (2) Western European countries.

\section{RESULTS AND DISCUSSION}

\section{Role of Pensions and Compensation in Servicemen Motivation for Entrepreneurship After Early Retirement}

The system of pensions and compensation for servicemen is a crucial contextual variable in entrepreneurship development. We base our approach on economic theories of entrepreneurship, so-called "push" approach. The "push" theories regard entrepreneurship primarily as new business creation and as an alternative to avoid unemployment and psychological discomfort (Smaliukiene et al., 2012).

Early retirement goes along with pensions and compensations that are categorized as a passive labour market policy. On the one hand, passive policy represents protection mechanisms and ensures a certain income level. On the other hand, it has a major impact upon the gaining labour market adjustment capacity and financial incentive for entrepreneurship. While life expectancy and working age are increasing and birth rates are decreasing, in many EU countries pension reform, which is seeking to increase the retirement age, is being implemented (Table 2 and Table 3). This trend can be noted while analysing pension systems for military reforms.

In some countries (Ireland, Denmark, Great Britain, Croatia, Poland, the Netherlands, France, Germany) pension reforms for the servicemen are extending the retirement age for the servicemen and introducing more restrictions to early retirement.

Analyzing retirement provision for servicemen, countries can be divided into three groups. The first group consists of the countries where there is a constant rejuvenation of the military, and servicemen can retire more than a decade before the full retirement age. This group comprises the majority of our analyzed countries from CEE and WE: Ireland, Bulgaria, the Czech Republic, Estonia, Spain, Croatia, Latvia, Lithuania, Poland, Romania, Slovakia, Slovenia, and Finland. The second group consists of countries where servicemen can retire 6-10 years earlier than other professionals. These are only countries of Western Europe: UK, the Netherlands and Germany. The third group consists of countries where the retirement age for the servicemen is close to the full retirement age ( 5 years or less before the latter). These are also countries of Western Europe: Austria, Belgium, Denmark, and Luxembourg. 
In all analyzed countries servicemen may terminate their military service before the early retirement age. In some Western European countries (Germany, the UK, France), such persons can benefit from the reintegration programs for servicemen.

Table 2. Retirement age for servicemen

\begin{tabular}{|c|c|c|}
\hline \multirow[b]{2}{*}{ Country } & \multicolumn{2}{|c|}{ Age of retirement } \\
\hline & Full retirement (men) & $\begin{array}{l}\text { Retirement of military } \\
\text { personnel }^{1} \text { (average) }\end{array}$ \\
\hline Austria & 65 & $50-65$ \\
\hline Belgium & 65 & 60 \\
\hline Bulgaria & 63 & $52-54$ \\
\hline Croatia & 65 & 45 \\
\hline Cyprus & 65 & . \\
\hline Czech Republic & 62 & 42 \\
\hline Denmark & 65 & 60 \\
\hline Estonia & 63 & 52 \\
\hline Finland & $62-68$ & $46^{2}$ \\
\hline France & 62 & $45-57$ \\
\hline Germany & 65 & $55-65$ \\
\hline Greece & 67 &. \\
\hline Hungary & 62 & . \\
\hline Iceland & 67 & . \\
\hline Ireland & 65 & $47-63$ \\
\hline Italy & 66 & . \\
\hline Latvia & 62 & 43 \\
\hline Lithuania & 62.8 & 47 \\
\hline Luxembourg & 65 & 60 \\
\hline Malta & 61 & . \\
\hline Netherlands & 65 & $60^{3}$ \\
\hline Norway & 67 & . \\
\hline Poland & 65 & 45 \\
\hline Portugal & 65 & \\
\hline Romania & 64 & $55^{4}$ \\
\hline Slovakia & 62 & 40 \\
\hline Slovenia & 63 & 45 \\
\hline Spain & 65 & $45-58$ \\
\hline Sweden & $61-67$ &. \\
\hline United Kingdom & 65 & $55-60$ \\
\hline
\end{tabular}

Source: own study.

Pension received by servicemen is calculated using different methods, yet compared to previously received salary, it remains substantially lower. In some cases laws are being adopted to prevent retired servicemen from pension reduction due to a new state pension system (France) or when they are recruited in a public or private sector (Croatia).

1 The average retirement age of officers is provided in case where soldiers are serving under term contracts.

${ }^{2}$ The average retirement age for the last few years has been 52 years (counting those who are retiring after full service) and 46 years (counting also those who retiring before full service years.

${ }^{3}$ The retirement age for officers of the Navy is 58 years, for officers of the Army and Air force is 60 years.

${ }^{4}$ It is foreseen to increase retirement age up to 60 . 
Grouping countries by passive labour market policy regarding motivation factors for entrepreneurship, we cannot see any links to the prevailing social system models, so we can assume that this is rather related to the different development of police and military as a special institution in each country. At the same time there is a clear trend to provide bigger financial support (higher pensions) in cases where early retirement age is close to full retirement age; and this is more common in Western European countries.

Table 3. Existing and expected retirement age

\begin{tabular}{|c|c|c|c|c|c|c|}
\hline \multirow{2}{*}{ Country } & \multicolumn{3}{|c|}{ Male } & \multicolumn{3}{|c|}{ Female } \\
\hline & 2010 & 2020 & 2060 & 2010 & 2020 & 2060 \\
\hline Austria & 65 & 65 & 65 & 60 & 60 & 65 \\
\hline Belgium & 65 & 65 & 65 & 65 & 65 & 65 \\
\hline Bulgaria & 63 & 63 & 65 & 60 & 60 & 63 \\
\hline Croatia & 62 & 62 & 62 & 62 & 62 & 62 \\
\hline Cyprus & 65 & 65 & 65 & 65 & 65 & 65 \\
\hline Czech R & 62 y 2 m & 63 y $8 \mathrm{~m}$ & 69 y $4 \mathrm{~m}$ & 58 y $8 \mathrm{~m}$ & 61 y $8 \mathrm{~m}$ & 69 y $4 \mathrm{~m}$ \\
\hline Denmark & 65 & 66 & 68 & 60 & 66 & 68 \\
\hline Estonia & 63 & $63 y 9 m$ & 65 & 61 & $63 y 9 m$ & 65 \\
\hline Finland & 62 & 65 & 65 & 62 & 65 & 65 \\
\hline France & 62 & 62 & 62 & 57.9 & 61.7 & 62 \\
\hline Greece & 65 & 65 & 69.4 & 60 & 65 & 69.4 \\
\hline Iceland & $60-65$ & $62-67$ & $62-67$ & $60-65$ & $62-67$ & $62-67$ \\
\hline Ireland & 66 & 66 & 68 & 66 & 66 & 68 \\
\hline Italy & 65 & 65.8 & 67 & 65 & 65.8 & 67 \\
\hline Latvia & 65 & 65 & 65 & 60 & 60 & 60 \\
\hline Lithuania & 65 & 65 & 65 & 65 & 65 & 65 \\
\hline Luxembourg & 61 & 63 & 65 & 60 & 63 & 65 \\
\hline Malta & 65 & 65 & 65 & 65 & 65 & 65 \\
\hline Netherlands & 67 & 67 & 67 & 67 & 67 & 67 \\
\hline Norway & 65 & 65 & 65 & 65 & 65 & 65 \\
\hline Poland & 65 & 67 & 67 & 60 & 62 & 67 \\
\hline Portugal & 64 & 65 & 65 & 59 & 61 & 63 \\
\hline Romania & 63 & 63 & 63 & 61 & 61 & 61 \\
\hline Slovakia & $63-68$ & $63-68$ & $63-68$ & $63-68$ & $63-68$ & $63-68$ \\
\hline Slovenia & $61-67$ & $61-67$ & $61-67$ & $61-67$ & $61-67$ & $61-67$ \\
\hline Spain & 65 y 4 m & 66 y $11 \mathrm{~m}$ & 70 y 3 m & 60 y $4 \mathrm{~m}$ & 66 y $11 \mathrm{~m}$ & 70 y $3 \mathrm{~m}$ \\
\hline Sweden & 65 & $65 y 9 m$ & 67 & 65 & $65 y 9 m$ & 67 \\
\hline United Kingdom & 65 & 65 & 72.5 & 65 & 65 & 72.5 \\
\hline
\end{tabular}

Source: own elaboration based on (Eurostat data; The 2012 Ageing Report; OECD, 2013). 


\section{Active Labour Market Policy for Entrepreneurship Development: Four Types of Practices}

The dismissal from service occurs ten or even twenty years earlier than the full retirement age. People tend to look for new economic activities as occupational pension does not provide the same level of well-being, which they used to have in the military. On the basis of the practice of implementation of active labour market measures for retiring servicemen, countries are divided into four groups

The first group includes countries where servicemen go into early retirement and are subject to measures of reintegration into the labour market. These are Ireland, Great Britain, France, Poland, Romania, Croatia, Germany and Lithuania. Implementation of measures is coordinated by an institution of the National Defence and its priorities and implementation mechanisms are very different in each country. Looking from entrepreneurship development perspective, only few national programmes emphasize shaping entrepreneurship skills. Looking more deeply into the situation in CEE, Poland, Romania and Croatia could be presented as examples:

- Reintegration of Polish servicemen is organized in cooperation with central and local authorities, non-governmental education organizations and organizations that provide counselling on the labour market. Counselling for servicemen is provided individually as well as in trainings and seminars. There is also a personal psychological test that they need to complete. On the basis of it, occupation, places of work or retraining for self-employment are chosen. Professional counselling and training for the servicemen are provided by the same institutions that offer services for other Polish people.

- In Romania since 1998 restructuring military and reducing the number of servicemen, a retraining system for the reintegration into the labour market has been created for servicemen with terminated contracts. The program is as a necessary social measure, compensating for the social and material losses servicemen encountered during the restructuring process. It was designed in cooperation with Ministries of National Defence, Labour and National Education. Specialized units in the internal structure of the Ministry of Defence, coordinate the system of vocational retraining in military centres in different counties. District experts work in accordance with the procedures of vocational training. Program activities, i.e. counselling and training, are implemented by the National Employment Agency, controlled by the Ministry of Labour. Retraining system includes guidance that facilitates contact with the civil environment. The servicemen are provided with information, counselling and assistance in job search and self-employment.

- In Croatia reforming the system of Defence, a transition program has been designed for servicemen going into early retirement. The program is implemented by the Ministry of National Defence through programs of special assistance: information program, transition workshops program, vocational training program, employment assistance program and self-employment assistance program. Training is organized as a part of an educational program which includes: getting familiar with and increasing the state of consciousness of one's own potentials, individual preferences analysis, system of values and capabilities, testing one's communication and career skills, 
decision making process, setting objectives and, developing skills of presenting own professional profile. The workshop is carried out in a dynamic manner through interactive cooperation with the Program participants.

Entrepreneurship skills development differs country to country in Western Europe. Two examples - UK and France will be analysed in detail:

- In the UK reintegration into civil life, as well as other social services for servicemen, are provided by a contractor - a private company which has won the public tender. Counselling and training start immediately after making a decision to leave the military. A serviceman is first obliged to talk to the officers, who provide him/her with the general information, while an officer of individual training and reintegration advise him/her on the reintegration into the labour market. The officer helps the serviceman define further goals and create a personal reintegration plan. The plan could be oriented towards employment or towards entrepreneurship. On the basis of this plan, a private company continues to counselling him/her on employment and provide training. Reintegration in the UK is identified as a successful transition from the military life to the civilian world; it is mainly focused on the employment or selfemployment in the private sector. During the reintegration, information and counselling are provided that enable people to make more effective decisions for (self-) employability. A person leaving the military, on the basis of the number of years in service and his/her rank, is supported as the reintegration program is seen as a reward for the time spent in service.

- In France reintegration into civil life is associated with retraining. Retired servicemen can choose to use retraining for preparation for the employment or entrepreneurship activities. Career officers or people working under a contract of employment can benefit from counselling on assessment and guidance in order to prepare for the return to civilian life. They can also benefit from professional training or assistance in job search. Reintegration program is of two types - focused on employment or selfemployment in the private sector, where retraining is linked to the skills required, or transferred to the civil service. The gradual transition from military service to work in the public sector is one of the state's priorities of human resource policy. Both types of reintegration program consist of four phases: information provision, guidance, training and recruitment. Implementation of the program and payment of benefits is gradually being transferred from the Mobile Defence Agency to the National Employment Agency.

The second group consists of countries which have reintegration program for the servicemen although the difference between their retirement age and the full retirement age is little (less than 10 years). These are only two Western European countries: Belgium and Germany. In Belgium the difference between the retirement age for servicemen and the full retirement age is only 5 years whereas the difference between the pension and previous salary is only 15 percent, i.e. servicemen go into early retirement at such age and with the financial backing that there is no motivation to look for a new job or start entrepreneurship activities. This reintegration program is a relic of the time when the servicemen could retire at a younger age. Currently reintegration programs are mostly directed to those who leave the service voluntarily having secured 
the minimum or slightly higher pension. These servicemen go to the early retirement at 40-45 and the pension is usually not paid until they are of a particular age (it is about 60). Meanwhile in Germany, the difference between the retirement age for servicemen of different categories and the full retirement age is 9 years.

- In Belgium reintegration program is available only to non-commissioned officers and career officers. The program itself is directed to vocational retraining of skills which could be used for new employment or for self-employment. Servicemen who want to leave the military service and find a new job in another field (in private or public sectors or work on their own) can get help from a specialized office. Retraining is finished when a person starts a new job. The servicemen can choose in which, private or public, sector they want to continue their career. The program is basically focused on the employment or self-employment in the private sector.

- In Germany the reintegration of servicemen into civil life is mostly related to the military reform, i.e. the reduction or rejuvenation of the military. Measures of reintegration are long-term and systematic; however, they are employed only during the period of the military reform. Full reintegration program is only for the servicemen serving under long-term contracts. Servicemen, serving under short-term contracts, at the end of their service can benefit from a partial reintegration package, which gives them personal training and professional qualifications. They are subject to active labour market measures that encourage professional development. During this learning period they receive remuneration. During full reintegration program, just like in Belgium, the servicemen are given long-term (up to three years) retraining leave and if the salary is lower than that obtained in the military when working for another employer or by self-employment, it remains the same.

The third group consists of countries where servicemen go into early retirement, but are not subject to special measures of reintegration. These are mixture of CEE and WE countries: Estonia, Latvia, Slovakia and Finland. In these countries servicemen who have completed the service are not attributed to the special group which should be given special attention and individual measures. Measures of reintegration into the civil life for the servicemen, who have completed their service, are given just like to the other members of the social system. Retired serviceman can benefit from national or regional entrepreneurship development programmes as other citizens.

The fourth group consists of countries where servicemen are not subject to early retirement or reintegration programs. These are only Western European countries: Denmark, the Netherlands and Luxembourg. In these countries servicemen retire at the age of 60 which is five years earlier than the full retirement age; however, it is not considered early retirement. Persons who retire earlier can apply for support to national or regional programmes for entrepreneurship skills development.

\section{CONCLUSIONS}

The results of the comparative analysis of policies on entrepreneurship development of early retired serviceman point out the fact that practice for entrepreneurship skills development of early retired servicemen varies across EU member states. Analysing retirement practice of the military in EU countries, the trend of military rejuvenation is 
noted. This trend forces to cut middle-age people into early retirement. It means that they will have to reintegrate into the labour market in order to maintain a similar level of well-being for themselves and their families. Accordingly, the entrepreneurship skills development is not only to prepare servicemen, who are being dismissed from the service, for the new economic activities, but to create conditions for their successful reintegration into civilian life.

The analysis shows that the impact of specific entrepreneurship development programmes for servicemen is quite limited in all analysed countries. Active labour market policies only seldom include measures for entrepreneurship skills development; type, intensity and effectiveness of these policies vary across countries.

The value added of this analysis lies in grouping countries according to intensity of reintegration programmes and the impact towards entrepreneurship development. The first group includes countries where servicemen go into early retirement and are subject to measures of reintegration into civil life. The group consists of mixture of CEE and WE countries: Croatia, France, Great Britain, Germany, Ireland, Lithuania Poland, and Romania. Some of activities for entrepreneurship skills development are included into reintegration programs. In CEE the main emphasis is put on self-development programs, while in WE more time and resources are devoted to start-up activities. In Poland there are psychological tests for self-evaluation, while in Croatia the main emphasis is on individual preferences analysis, testing one's communication and career skills, decision making process and individual's objectives. The system of reintegration and especially entrepreneurship development activities are half-way developed in CEE because of the lack of resources or priorities. As alternative, a comprehensive reintegration system is developed in France where gradual transition from military service to civil life is one of the state's priorities of human resource policy. Retraining is long-lasting and linked to the skills required for employment or self-employment. At the same time there is no evidence that entrepreneurship development of early retired servicemen is priority in any of analyzed countries.

The second group consists of countries which have reintegration program for the servicemen although the difference between their retirement age and the full retirement age is little (less than 10 years). These are Belgium and Germany. The countries of the first and second groups provide most inclusive reintegration programmes that could lead to entrepreneurship skills development of retired servicemen. The third group includes countries where servicemen go into early retirement, but are not subject to special measures of reintegration. These are Estonia, Latvia, Slovakia and Finland. In these countries servicemen who have completed the service are not attributed to the special group which should be given special attention and individual measures. Measures are given just like to the other members of the society and highly depend on general entrepreneurship development programs and activities in the country. The fourth group pools countries where servicemen are not subject to early retirement. These are Denmark, the Netherlands and Luxembourg.

This study has several limitations that should be identified while interpreting the results. The first limitation is that the questionnaire relies upon purchasing one-side representation: only institutions were surveyed. Entrepreneurship skills development 
refers to institutional and individual agency. Individual internal motivation is one of the biggest factors that determine entrepreneurship activity.

Another limitation of the research lies in the representation of the countries practices. The results of institutional survey represents only half of EU member countries practices, while response rate from authorities was 55\%. Finally, although the literature suggests a more detailed indicators for entrepreneurship skills development, more research may be necessary to empirically test whether those indicators are adequate in measuring the opportunities for entrepreneurship of servicemen.

For the conclusions, some policy implications could be drawn. The impact of specific entrepreneurship skills development programmes for servicemen has to be increased in all analysed countries, as servicemen are a highly potential group of entrepreneurs. Service in military for a few decades gives highly specific competencies necessary for entrepreneurship, like clear communication, group leadership, problem solving, and risktaking. At the same time this group is highly specific and requires specific entrepreneurship skills development programmes that utilise servicemen competencies and add specific knowledge and skills needed within a business environment.

\section{REFERENCES}

Brown, P. A., \& Gross, C. (2011). Serving those who have served-managing veteran and military student best practices. The Journal of Continuing Higher Education, 59(1), 45-49.

Caligiuri, P., Noe, R., Nolan, R., Ryan, A. M., \& Drasgow, F. (2011). Training, developing, and assessing cross-cultural competence in military personnel. Rutgers - the State University Picataway, New Jersey. Retrieved on December 13, 2013, from http://www.dtic.mil/cgibin/GetTRDoc?AD=ADA559500

Cawley, J., \& Maclean, J. C. (2012). Unfit for service: the implications of rising obesity for US military recruitment. Health Economics, 21(11), 1348-1366.

Chandra, R. (2013). Entrepreneurship: An Ideal Way of Success. Kolkata: BookRix.

De la Porte, C., \& Jacobsson, K. (2012). Social investment or recommodification? Assessing the employment policies of the EU member states. In N. Morel, B. Palier, \& J. Palme (Eds.), Towards a social investment state? (pp. 117-152). Bristol: Policy Press.

Early, J. M. (2011). Transition home: an exploratory study of the transition from military to civilian life among veterans of Operation Enduring Freedom and Operation Iraqi Freedom. Smith College School for Social Work, Northampton, Mass. Retrieved on December 18, 2013, from https://dspace.smith.edu/handle/11020/22974

Haerem, T., Kuvaas, B., Bakken, B. T., \& Karlsen, T. (2011). Do military decision makers behave as predicted by prospect theory?. Journal of Behavioral Decision Making, 24(5), 482-497.

Henning, C. A. (2011). Military Retirement: Background and Recent Developments. DIANE Publishing.

Hope, J. B., Oh, B., \& Mackin, P. C. (2011). Factors affecting entrepreneurship among veterans. Small Business Research Summary.

OECD (2013). Ageing and Employment Policies - Statistics on average effective age of retirement. Organization for Economic Cooperation and Development. Retrieved on December 15, 2013, from http://www.oecd.org/employment/emp/ageingandemploymentpolicies-statisticsonave rageeffectiveageofretirement.htm 
Ruiz, J., \& Morrow, E. (2005). Retiring the old centurion: life after a career in policing - an exploratory study. International Journal of Public Administration, 28(13-14), 1151-1186.

Šileika, A., \& Bekerytè, J. (2013). The theoretical issues of unemployment, poverty and crime coherence in the terms of sustainable development. Journal of Security and Sustainability Issues, 2(3), 59-70.

Smaliukienè, R., Dudzevičiūtè, G., \& Bekešienè, S. (2012). Counselling for self-employment: the application of decision support system. Verslas: teorija ir praktika, 1, 18-26.

Smaliukiene, R. (2014). Towards sustainable employability: European practice in officers and servicemen reintegration after early retirement, Journal of Security and Sustainability Issues (accepted for publication).

The 2012 Ageing Report. Economic and budgetary projections for the 27 EU Member States (2010-2060). European Union. Retrieved on December 19, 2013, from http://ec.europa.eu/ economy_finance/publications/european_economy/2012/pdf/ee-2012-2_en.pdf

Veterans Fact Sheet. U.S. Small Business Administration. Retrieved on December 19, 2013, from http://www.sba.gov/sites/default/files/Veterans\%20fact\%20sheet_7_6_12.pdf

Vigoda-Gadot, E., Baruch, Y., \& Grimland, S. (2010). Career transitions: An empirical examination of second career of military retirees. Public Personnel Management, 39(4), 379-404.

Wood, M., Bianchi, A., \& Kucik, P. (2012). Articulating Value: A framework for Evaluating Military Retirement Alternatives. Operations Research Center. US Military Academy, West Point, New York. Retrieved on December 19, 2013, from http://oai.dtic.mil/oai/oai?verb=getRecord\&meta dataPrefix=html \&identifier=ADA567192

\section{Author}

\section{Rasa Smaliukiene}

Professor at Vilnius Gediminas Technical University and General Jonas Zemaitis Lithuanian Military Academy (Lithuania). Research interests: entrepreneurship, social responsibility, leadership.

\section{Correspondence to:}

Prof. Rasa Smaliukiene, PhD

Vilnius Gediminas Technical University

Faculty of Business Management

Saulètekio al. 11, LT-10223 Vilnius, Lithuania

rasa.smaliukiene@vgtu.It 